\title{
PLANT DISTANCE AND DOSAGE OF ORGANIC FERTILIZER INFLUENCE RESULTS OF EGG CABBAGE PLANT (BRASSICA OLERACEAE VAR. CAPITATA L)
}

\author{
KETUT TURAINI INDRA WINTEN ${ }^{1)}$, PANDE GEDE GUNAMANTA ${ }^{2)}$, \\ ANAK AGUNG GEDE PUTRA ${ }^{3)}$ \\ PS. Agroteknologi Fakultas Pertanian Universitas Tabanan, Bali
}

e-mail:. ${ }^{1)}$ nusi.winten@gmail.com, ${ }^{2)}$ gunamanta.pandegede@gmail.com, ${ }^{3)} a a \_g d \_p u t r a @ y a h o o . c o m$

\section{ABSTRAK}

Rendahnya hasil kol sering dikaitkan dengan rendahnya kandungan bahan organik tanah. Jarak tanam yang tidak tepat juga berkontribusi pada hasil rendah tanaman kubis. Pemberian pupuk organik dengan dosis yang tepat dan pengaturan jarak yang tepat juga diharapkan dapat meningkatkan kesuburan tanah dan pada akhirnya meningkatkan hasil tanaman kubis.

Penelitian ini dilakukan di lapangan dari bulan April hingga Juli 2018 di Subak Gede Bungan Kapal, Desa Tunjuk, Kecamatan Tabanan, Kabupaten Tabanan. Perawatan diatur secara faktorial dalam Rancangan Acak Kelompok (RAK). Dua perlakuan yang dipelajari dalam penelitian ini adalah jarak tanam $(30 \mathrm{~cm} \times 40 \mathrm{~cm} ; 30 \mathrm{~cm} \times 40 \mathrm{~cm} ; 30 \times 50 \mathrm{~cm})$ dan pupuk organik (Petroganik) (0 tha-1; $1 \mathrm{t} \mathrm{ha}-1 ; 2 \mathrm{t} \mathrm{ha}-1 ; 3$ tha-1). Perawatan diulangi tiga kali.

Hasil penelitian menunjukkan bahwa interaksi antara perlakuan jarak dan penggunaan dosis pupuk organik tidak berpengaruh signifikan pada semua parameter yang diamati.

Perlakuan jarak tanam berpengaruh signifikan terhadap diameter tanaman komersial -1, bobot brangkasan segar ha-1, dan memiliki efek yang sangat signifikan terhadap bobot tanaman ha-1, dan bobot ha- tanaman komersial. 1. Berat komersial tertinggi k-ha ha-1 diperoleh pada jarak tanam $30 \times 50 \mathrm{~cm}(\mathrm{~J} 3)$ $525,86 \mathrm{~kg}$, meningkat secara signifikan sebesar 74,80\% dibandingkan dengan jarak $30 \times 30 \mathrm{~cm}(\mathrm{JI})$ yaitu $299,12 \mathrm{~kg}$.

Perlakuan dosis pupuk organik berpengaruh sangat nyata terhadap bobot tanaman ha-1, bobot tanaman komersial ha-1, diameter tanaman komersial-1 tetapi tidak berpengaruh signifikan terhadap bobot segar brangkasan ha-1. Berat komersial tertinggi ha-1 krop diperoleh pada dosis pupuk organik 2 tha-1 dari 444,23 $\mathrm{kg}$ (P2) meningkat 58,30\% dibandingkan dengan dosis 0 t ha-1 (P0) dari 280,62 kg.

Kata kunci: jarak tanam, dosis pupuk organik, kubis telur (Brassica oleraceae var. Capitata L.)

\section{ABSTRACT}

The low yield of cabbage is often associated with the low content of soil organic matter. The inappropriate planting distance also contributes to the low yield of the cabbage plant. The provision of organic fertilizer with the right dosage and setting the right spacing is also expected to increase soil fertility and ultimately increase results of cabbage plants.

This research was conducted in the field from April to July 2018 in Subak Gede Bungan Kapal, Tunjuk Village, Tabanan District, Tabanan Regency. Treatment was arranged in a factorial manner in a Randomized Block Design (RBD). Two treatments studied in this study were plant spacing $(30 \mathrm{~cm} \mathrm{x} 40 \mathrm{~cm} ; 30 \mathrm{~cm} \times 40$ $\mathrm{cm} ; 30 \times 50 \mathrm{~cm}$ ) and organic fertilizer (Petroganic) (0 $\mathrm{t}$ ha-1; $1 \mathrm{t}$ ha- $1 ; 2 \mathrm{t}$ ha $-1 ; 3 \mathrm{t}$ ha-1). The treatment was repeated three times.

The results showed that the interaction between the treatment of spacing and the use of doses of organic fertilizer had no significant effect on all observed parameters.

The treatment of spacing has a significant effect on the diameter of the commercial $\mathrm{crop}^{-1}$, the weight of fresh stover $\mathrm{ha}^{-1}$, and has a very significant effect on the weight of crop ha ${ }^{-1}$, and the weight of commercial crop ha ${ }^{-1}$. The highest weight of commercial $\mathrm{k}$-ha ha ${ }^{-1}$ was obtained at a plant spacing of $30 \times 50 \mathrm{~cm}\left(\mathrm{~J}_{3}\right)$ of $525.86 \mathrm{~kg}$, significantly increasing by $74.80 \%$ compared to a spacing of $30 \times 30 \mathrm{~cm}\left(\mathrm{~J}_{1}\right)$ which was 299.12 $\mathrm{kg}$. 
The treatment of organic fertilizer dosage has a very significant effect on the weight of crop ha ${ }^{-1}$, weight of commercial crop ha ${ }^{-1}$, commercial crop diameter ${ }^{-1}$ but has no significant effect on the fresh weight of stover ha $\mathrm{h}^{-1}$. The highest weight of commercial ha ${ }^{-1} \mathrm{krop}$ obtained at the dose of organic fertilizer $2 \mathrm{tha} \mathrm{a}^{-1}$ of $444.23 \mathrm{~kg}\left(\mathrm{P}_{2}\right)$ increased by $58.30 \%$ compared to the dose of $0 \mathrm{t} \mathrm{ha}^{-1}\left(\mathrm{P}_{0}\right)$ of $280.62 \mathrm{~kg}$.

\section{Keywords: spacing, dose of organic fertilizer, egg cabbage (Brassica oleraceae var. Capitata L.)}

\section{INTRODUCTION}

Egg cabbage (Brassica oleraceae var. Capitata L.) is a vegetable that contains high nutritional value, including carbohydrates, proteins, fats, minerals and vitamins A, B1, B2 and vitamin C, vitamins - these vitamins act as regulatory substances and a very important protector in the body and maintaining a healthy body (Sunarjono, 2004), so that it is consumed by many people.

Now cabbage has been widely cultivated in highlands with centers in Dieng, Wonosobo, Tawangmangu, Kopeng, Purbalingga, Malang, Garut and Bali. Because these plants have very high economic value as well as vegetables with good taste.in various ways, one of them is by setting the spacing and giving organic fertilizer. Setting the spacing is very influential on the growth and yield of cabbage plants, especially during the crop formation period, which is very varied between ovoid, flat, to cone shaped. Thus the spacing functions to utilize light effectively and the absorption of nutrients evenly(Rukmana, 2005)

Plant spacing will determine the height and number of plant populations in broad unity. Generally high production of broad unity will be achieved in a high population because of the maximum use of light at the beginning of growth, then competition occurs so that the speed of plant growth decreases. Plants respond by reducing size, both on all parts of plants and certain parts of plants so that the results of each individual plant are low. The spacing is very closely related to the needs of plants for nutrients, water, sunlight and other growth factors, regulating the spacing is very necessary so that plants can utilize the growth factors efficiently and effectively. In determining the spacing, competition between plants that may occurs in using growth factors that will affect overall results.

The results of Erwin, et al (2015) study of cabbage (Brassica oleracea L.) stated that the treatment of plant spacing significantly affected the observation of plant height, at the age of 42 days after planting, obtained a spacing of $40 \mathrm{~cm} \times 40 \mathrm{~cm}=37.8$; spacing of $50 \mathrm{~cm} \times 50 \mathrm{~cm}=40.4$ and spacing of $60 \mathrm{~cm} \times 60 \mathrm{~cm}$ $=40.8$, and Area of Leaves at 21 days after planting obtained a spacing of $40 \mathrm{~cm} \mathrm{x} 40 \mathrm{~cm}=33.82$, spacing of $50 \mathrm{~cm} \times 50 \mathrm{~cm}=33.90$, Planting Distance $60 \mathrm{~cm} \times 60 \mathrm{~cm}=38.75$, and weight of crop at the age of 42 days after planting, spacing of $40 \mathrm{~cm} \times 40 \mathrm{~cm}=1.10 \mathrm{~kg}$, spacing of $50 \mathrm{~cm} \times 50 \mathrm{~cm}=1.52 \mathrm{~kg}$ and spacing of 60 $\mathrm{cm} \times 60 \mathrm{~cm}=40.88 \mathrm{~kg}$. The study of Purnama et al. (2013) treatment of spacing affected the increase in leaf number, leaf length, plant fresh weight, plant weight consumption, plant dry weight and harvest index, treatment of $20 \mathrm{~cm} \times 20 \mathrm{~cm}$ spacing was the best spacing because it could increase growth and optimal mustard yields of 11 leaves, $17.94 \mathrm{~cm}$ of leaf length, $89.46 \mathrm{~g}$ of fresh fresh weight, $64.62 \mathrm{~g}$ of weighing plant weight, and $7.61 \mathrm{~g}$ of dry weight.

Addition of organic matter to the planting media is an effort made to increase the fertility of the growing media so that the supply of nutrients for plant growth and development will be more fulfilled. The main benefit of organic fertilizers is to improve soil structure by providing space for soil for air and water. Soil structure that is very loose like sandy soil, organic material will bind the grains of soil so that it is denser and not destroyed (Lingga and Marsono, 2004). In addition, the use of organic fertilizers is also very helpful in increasing media porosity, increasing the number and microbial activity and stimulating the growth of roots and shoots (Mulat, 2003).

One of the commonly used organic fertilizers is Petroganic Organic Fertilizer with the composition of organic C content of $12.5 \%, \mathrm{C} / \mathrm{N}$ ratio of $10-25 \%, \mathrm{pH} 4-8$, and moisture content of $4-12 \%$, recommended use of Petroganic fertilizers for pulses of crops $2 \mathrm{t} \mathrm{ha}^{-1}$. The results of the research by Karnata et al. (2012) for shallots with Petroganic fertilizer dosages at various levels were able to increase oven dry weight of tubers $^{-1}$ at doses of $3 \mathrm{t} \mathrm{ha}^{-1}$ giving the heaviest oven weight of clump ${ }^{-1}$ tubers of $2.61 \mathrm{~g}^{\text {increased by } 1.28 \%}$ compared to $0 \mathrm{t}$ dose of Petroganic fertilizer $1.14 \mathrm{~g}$. The results of the study by Lamusi et al. (2014) showed that Petroganic fertilizer had an influence on the growth of cucumber plants on variable plant height, stem diameter, weight $\operatorname{plot}^{-1}$ and weight plant fruit ${ }^{-1}$, but did not have an effect on leaf area index variables. The treatment of $\mathrm{P}_{2}$ (32 g / plant) is the best treatment that affects growth and yield. The results of Wisardja's research (2011) state that the treatment of Petroganic fertilizer dose of 2 tons ha $^{-1}$ significantly affected the leaf area index of corn plants, the weight of $12 \%$ moisture content and very significant effect on oven dry weight of 1,000 seeds and oven dried ha ${ }^{-1}$ results. Likewise, the results of Talkah (2007) also stated that the 
treatment of Petroganic organic fertilizer dosage $2 \mathrm{t} \mathrm{ha}^{-1} \mathrm{a}$ very significant effect on the observed variables of leaf number, plant length and weight of the fruit of the melon plant.

Based on the explanation above, the problem was raised whether there was an effect on the distance of planting and dosage of organic fertilizer on the yield of eggcabbage (Brassica oleraceae var. Capitata L.).

This study was conducted to determine the effect of planting distance and dosage of organic fertilizers and their interactions on the yield of eggcabbage (Brassica oleraceae var. Capitata L.). It is assumed that the treatment of spacing and the administration of doses of organic fertilizer had an effect on the yield of egg cabbage (Brassica oleraceae var. Capitata L.).

\section{RESEARCH METHOD}

This research is a factorial experiment using Randomized Block Design (RBD). The treatment that was tried consisted of 2 factors, namely planting distance and organic fertilizer, in this case Petroganic organic fertilizer was used. Plant spacing factor consists of 3 , namely: $J_{1}=30 \mathrm{~cm} \times 30 \mathrm{~cm}, \mathrm{~J}_{2}=30 \mathrm{~cm} \times 40 \mathrm{~cm}, \mathrm{~J}_{3}=$ $30 \mathrm{~cm}$ x $50 \mathrm{~cm}$. Petroganic organic fertilizer dosage factor consists of 4 levels, namely: $\mathrm{P}_{0}=0 \mathrm{t} \mathrm{ha} \mathrm{a}^{-1}, \mathrm{P}_{1}=1 \mathrm{t}$ $\mathrm{ha}^{-1}, \mathrm{P}_{2}=2 \mathrm{t} \mathrm{ha}^{-1}, \mathrm{P}_{3}=3 \mathrm{tha}^{-1}$. From these two factors 12 combinations were obtained with repetitions three times so that there were 36 observation units. Placement of treatment was done randomly in the research plot. The research was conducted in SubakGede Bungan Kapal, Tunjuk Village, Tabanan District, Tabanan Regency. It runs from April to July 2018.

The materials used in this study were cabbage seeds, Petroganic organic fertilizers. While the tools used in this study are hoes, rakes, meters, plastic straps, buckets, handsprayers, scales, ovens, stationery and others. Land preparation before the study was carried out by cultivating the land, aimed at reversing the soil so that substances that could harm the plant could be lost. Then the plot was made with a plot size of $1.5 \mathrm{~m} \mathrm{x}$ $2.0 \mathrm{~m}$, the distance between plots was $50 \mathrm{~cm}$ and the distance between replications was $100 \mathrm{~cm}$, each replication was divided into 12 treatments. Two weeks before being transferred to the field, seed germination was carried out using seedling media containing soil mixtures with manure, after the seeds had grown into seeds with the characteristics that the seeds already had 2-3 large leaves, then planting by way of spitting on each research plot with a depth of $3-4 \mathrm{~cm}$, each planting hole is planted with one seedling. Giving Petroganic organic fertilizer in stages, first given at the age of the plant 7 days after planting, the second giving at the age of 14 days after planting, the dose used is in accordance with the treatment.

Maintenance of plants includes watering, weeding, control of pests and diseases. Watering is carried out according to the needs and conditions of the plants, weeding is done 3 times the age of plants 14, 30, 44 days after planting, while pest and disease control is carried out 4 days starting from the age of the plant 14 days after planting.

Observations were made on yield variables: weight of crop ha ${ }^{-1}$, weight of commercial crop ha ${ }^{-1}$, diameter of commercial $\mathrm{crop}^{-1}$, weight of fresh stover $\mathrm{ha}^{-1}$. Harvesting is done on 77-day-old plants.

The results of the observational data were then analyzed statistically according to the design used. If a single factor showed a real or very real effect followed by a LSD test at the level of 5\%. If the interaction between the two treatments shows a real or very real influence, then continue using the Duncan test level of 5\% (Gomez and Gomez, 1995).

\section{RESULTS AND DISCUSSION}

\section{Research Result}

The results of statistical analysis show that the interaction between plant treatment and the use of organic fertilizer dosages had no significant effect on all observed parameters. The treatment of spacing has a significant effect on the diameter of the commercial $\mathrm{crop}^{-1}$, the weight of fresh stover ha ${ }^{-1}$, and has a very significant effect on the weight of crop ha ${ }^{-1}$, and the weight of commercial crop ha ${ }^{-1}$. The treatment of the dosage of organic fertilizer has a very significant effect on the weight of crop ha ${ }^{-1}$, the weight of commercial crop $\mathrm{ha}^{-1}$, the commercial diameter of the crop $^{-1}$ but does not significantly affect the fresh weight of stover $\mathrm{ha}^{-1}$. The significance of the effect of planting distance $(\mathrm{J})$ and dosage of organic fertilizer and its interaction between the two treatments ( $\mathrm{J} \times \mathrm{P})$ on the observed parameters is presented in (Table 1). 
Table 1. Significance of Planting Distance (J) and Organic Fertilizer Dose (P) and its Interaction (JxP) the Parameters Observed in Cabbage Plants

\begin{tabular}{|c|c|c|c|c|}
\hline \multirow[t]{2}{*}{ No } & \multirow[t]{2}{*}{ Parameters observed } & \multicolumn{3}{|c|}{ Treatment } \\
\hline & & $\mathbf{J}$ & $\mathrm{P}$ & $\mathrm{J} \times \mathrm{P}$ \\
\hline 1. & Weight of crop ha ${ }^{-1}(\mathrm{~kg})$ & $* *$ & $* *$ & $\mathrm{~ns}$ \\
\hline 2. & Weightcommercial crop ha ${ }^{-1}(\mathrm{~kg})$ & $* *$ & $* *$ & $\mathrm{~ns}$ \\
\hline 3. & Diamter commercial crop $^{-1}(\mathrm{~cm})$ & $*$ & $* *$ & $\mathrm{~ns}$ \\
\hline 4. & Fresh weight of stover ha ${ }^{-1}(\mathrm{~kg})$ & $*$ & ns & ns \\
\hline
\end{tabular}

Source: primary data processed

$\mathrm{ns}=$ non significant $(\mathrm{p} \geq 0,05), \mathrm{J}=$ spacing, ${ }^{*}=$ significant $(\mathrm{p}>0,05), \mathrm{P}=$ organic fertilizer dose

$* * \quad=$ significant $(\mathrm{p}<0,01) \quad \mathrm{J} \times \mathrm{P}=$ interaction between treatments

\section{Weight of Crop ha' ${ }^{-1}(\mathrm{~kg})$}

The results showed the treatment of spacing and dosage of organic fertilizer had a very significant effect, while the interaction between the two treatments had no significant effect. The treatment of spacing has a very significant effect on the weight of $\mathrm{crop} \mathrm{ha}^{-1}(\mathrm{t})$ with a spacing of $30 \mathrm{~cm} \mathrm{x} 40 \mathrm{~cm}\left(\mathrm{~J}_{2}\right)$ indicating the highest crop weight which is equal to $992.31 \mathrm{t}$ not significantly different from $\mathrm{J}_{3}(946.77 \mathrm{~kg})$ or real increase $32.76 \%$ compared to the spacing of $30 \mathrm{~cm} \times 30 \mathrm{~cm}\left(\mathrm{~J}_{1}\right)$ which is $747.94 \mathrm{~kg}$. The dosage of organic fertilizer $3 \mathrm{t} \mathrm{ha}{ }^{-1}\left(\mathrm{P}_{3}\right)$ gave the highest ha ${ }^{-1}$ crop weight of $1021.92 \mathrm{~kg}$ not significantly different from $\mathrm{P}_{2}$ or increased by $55.08 \%$ compared with $\mathrm{P}_{0}$ of $658.95 \mathrm{~kg}$ (Table 2).

Table 2. Average Weight of Cropha ${ }^{-1}$, Weight Commercial Crop of ha ${ }^{-1}$, Diameter Commercial Crop ${ }^{-1}$, Fresh Weight of Stover ha ${ }^{-1}$ Due to Treatment of Spacing $(\mathrm{J})$ and Dosage of Organic Fertilizer (P)

\begin{tabular}{|c|c|c|c|c|}
\hline Treatment & $\begin{array}{c}\text { Weight of crop } \\
\text { ha }^{-1} \\
(\mathrm{~kg})\end{array}$ & $\begin{array}{l}\text { Weight commercial } \\
\text { crop ha }^{-1} \\
(\mathrm{~kg})\end{array}$ & $\begin{array}{c}\text { Diamter commercial } \\
\text { crop }^{-1} \\
(\mathrm{~cm})\end{array}$ & $\begin{array}{l}\text { Fresh weight of } \\
\text { stover ha }^{-1} \\
(\mathrm{~kg})\end{array}$ \\
\hline \multicolumn{5}{|l|}{ Planting Distance } \\
\hline $\mathrm{J}_{1}(30 \times 30 \mathrm{~cm})$ & $747,94 \mathrm{~b}$ & $299,12 \mathrm{~b}$ & $13,72 \mathrm{~b}$ & $1,26 \mathrm{bc}$ \\
\hline $\mathbf{J}_{2}(30 \times 40 \mathrm{~cm})$ & $992,31 \mathrm{a}$ & $335,29 \mathrm{~b}$ & $14,06 \mathrm{ab}$ & $1,38 \mathrm{~b}$ \\
\hline $\mathrm{J}_{3}(30 \times 50 \mathrm{~cm})$ & $946,77 \mathrm{a}$ & $525,86 \mathrm{a}$ & $14,11 \mathrm{a}$ & $1,56 \mathrm{a}$ \\
\hline BNT 5\% & 147,49 & 58,37 & 0,35 & 0,20 \\
\hline \multicolumn{5}{|l|}{ Dosageof Organic } \\
\hline Fertilizer & & & & \\
\hline $\mathrm{P}_{0}=0 \mathrm{t} \mathrm{ha}^{-1}$ & $658,95 \mathrm{c}$ & $280,62 \mathrm{c}$ & $13,44 \mathrm{~b}$ & $1,30 \mathrm{a}$ \\
\hline$P_{1}=1 \mathrm{tha}^{-1}$ & $890,99 \mathrm{~b}$ & $376,95 \mathrm{~b}$ & $14,02 \mathrm{ab}$ & $1,35 \mathrm{a}$ \\
\hline $\mathrm{P}_{2}=2 \mathrm{tha}^{-1}$ & $1010,82 \mathrm{a}$ & $444,23 \mathrm{a}$ & $14,15 \mathrm{a}$ & $1,38 \mathrm{a}$ \\
\hline$P_{3}=3 \mathrm{tha}^{-1}$ & $1021,92 \mathrm{a}$ & $445,22 \mathrm{a}$ & $14,25 \mathrm{a}$ & $1,52 \mathrm{a}$ \\
\hline BNT 5\% & 51,14 & 67,40 & 0,41 & $\mathrm{~ns}$ \\
\hline
\end{tabular}

Source: primary data processed

\section{Commercial Crop Weight ha ${ }^{-1}(\mathrm{~kg})$}

The results of statistical analysis showed that the treatment of spacing and dosage of organic fertilizer had a very significant effect, while the interaction of the two treatments had no significant effect on the weight of commercial crop ha ${ }^{-1}$ (Table 1 ).

The treatment of spacing has a very significant effect on the weight of commercial crop ha ${ }^{-1}$ with the weight of the commercial crop which is the highest given at a spacing of $30 \mathrm{~cm} \times 50 \mathrm{~cm}\left(\mathrm{~J}_{3}\right)$ of $525.86 \mathrm{~kg}$ significantly different from the denser spacing or increasing significantly by $75,80 \%$ compared to the spacing of $30 \mathrm{~cm} \times 30 \mathrm{~cm}\left(\mathrm{~J}_{1}\right)$ which is equal to $299.12 \mathrm{~kg}$ (Table 2).

The dosage of organic fertilizer $3 \mathrm{t} \mathrm{ha}^{-1}\left(\mathrm{P}_{3}\right)$ gives the highest commercial ha ${ }^{-1} \mathrm{krop}$ weight of $445.22 \mathrm{~kg}$ $\left(\mathrm{P}_{3}\right)$ but not significantly different from the dose of organic fertilizer $2 \mathrm{t} \mathrm{ha}^{-1}\left(\mathrm{P}_{2}\right)$ of $(444.23 \mathrm{~kg})$. The dose of organic fertilizer $3 \mathrm{t} \mathrm{ha}^{-1}\left(\mathrm{P}_{3}\right)$ increased by $58.65 \%$ compared to the dose of $0 \mathrm{t} \mathrm{ha}^{-1}\left(\mathrm{P}_{0}\right)$ of $280.62 \mathrm{~kg}$ (Table 2). 


\section{Diameter of Commercial Crop $\operatorname{crop}^{-1}(\mathrm{~cm})$}

The results of statistical analysis show that the treatment of spacing has a significant effect and the dose of organic fertilizer has a very significant effect, while the interaction of the two treatments has no significant effect on the diameter of the commercial $\operatorname{crop}^{-1}$ (Table 1).

The treatment of spacing has a significant effect on the diameter of the highest commercial $\mathrm{crop}^{-1}$ shown at a spacing of $30 \times 50 \mathrm{~cm}\left(\mathrm{~J}_{3}\right)$ which is $14.11 \mathrm{~cm}$, not significantly different from the spacing of $30 \mathrm{~cm} \times 40$ $\mathrm{cm}\left(\mathrm{J}_{2}\right)$ of $14.06 \mathrm{~cm}$, The lowest diameter of commercial crop ${ }^{-1}$ was shown at a spacing of $30 \mathrm{~cm} \mathrm{x} 30 \mathrm{~cm}$ at $13.72 \mathrm{~cm}$, increasing by $2.84 \%$ (Table 2 ).

The dosage of organic fertilizer $3 \mathrm{tha}^{-1}\left(\mathrm{P}_{3}\right)$ gives the highest commercial crop ${ }^{-1}$ crop diameter of 14.25 $\left(\mathrm{P}_{3}\right)$ increased by $6.03 \%$ compared to the dose of $0 \mathrm{t} \mathrm{ha}^{-1}\left(\mathrm{P}_{0}\right)$ of $13.44 \mathrm{~cm}$ (Table 2).

\section{Fresh Weight of Stover ha ${ }^{-1}(\mathbf{k g})$}

The results of statistical analysis showed that the treatment of spacing had a significant effect, and the dosage of organic fertilizer had no significant effect because the interactions of the two treatments had no significant effect on the fresh weight of stover ha-1 (Table 1).

The treatment of spacing has a significant effect on the fresh weight of stover ha ${ }^{-1}$ indicated by the spacing of $30 \mathrm{~cm} \times 50 \mathrm{~cm}\left(\mathrm{~J}_{3}\right)$, which is $1.58 \mathrm{~kg}$, significantly different from the denser spacing or increasing by $23.80 \%$ to the weight of fresh stover ha ${ }^{-1}$ as low as indicated by the spacing of $30 \mathrm{~cm} \mathrm{x} 30 \mathrm{~cm}\left(\mathrm{~J}_{1}\right)$ of $1.26 \mathrm{~kg}$ (Table 2).

The dosage of organic fertilizer $3 \mathrm{tha}^{-1}\left(\mathrm{P}_{3}\right)$ tended to give the highest fresh weight of stover ha ${ }^{-1}$ of 1.52 $\mathrm{kg}\left(\mathrm{P}_{3}\right)$ not significantly different from the lower dosage of organic fertilizer with an average organic fertilizer dose of $1.39 \mathrm{~kg}$ ( Table 2).

\section{Discussion}

The treatment of spacing $(\mathrm{J})$ has a significant effect on the fresh weight of stover ha ${ }^{-1}$ with the highest value at a spacing of $30 \mathrm{~cm} \times 50 \mathrm{~cm}\left(\mathrm{~J}_{3}\right)$ which is equal to $1.58 \mathrm{~kg}$ or $23.80 \%$ higher than the spacing of 30 $\mathrm{cm} \times 30 \mathrm{~cm}\left(\mathrm{~J}_{1}\right)$ of $1.26 \mathrm{~kg}$. Spacing greatly affects plant populations and light efficiency, also affects the competition between plants in using water and nutrients, thus affecting the results (Haryadi, 2002). This is indicated by the increasingly spacing of spacing increasing the weight of commercial crop ha ${ }^{-1}$ at a spacing of $30 \mathrm{~cm} \times 50 \mathrm{~cm}\left(\mathrm{~J}_{3}\right)$ of $525.86 \mathrm{~kg}$ and supported by crop weight ha ${ }^{-1}$ of $946.77 \mathrm{~kg}$ and diameter of commercial $\mathrm{crop}^{-1}$ of $14.11 \mathrm{~cm}$.

According to Suprapto (1992 in Erwin et al., 2015) aspects of using spacing provide implications for the results of broad unity, but also on the average size of cabbage produced. The spacing is cultivated regularly so that the plants get uniform growth space, and in easier maintenance and simplification in conducting weeding, the spacing is very influential on plant growth and formation of crop, close spacing increases humidity around the plant, this condition can spur growth and development disturbing organisms, besides that it also affects the reception of sunlight on each plant so that it can affect the growth and yield of cabbage plants.

Increasing the dosage of organic fertilizer from 0 to $2 \mathrm{t} \mathrm{ha}^{-1}$ increased the weight of commercial crop ha ${ }^{1}$ with the highest yield at a dose of $2 \mathrm{t} \mathrm{ha}^{-1}$ which was $444.23 \mathrm{~kg}$ and the lowest at a dose of $0 \mathrm{tha}^{-1}$ at 280.62 $\mathrm{kg}$. With heavy fertilization, apparently a larger population will bring in efficient use of fertilizers, because of the efficient use of light (Harjadi. 2002). According to Gomies et al., (2012) organic fertilization can play a role in mobilizing or bridging nutrients that are already in the soil forming ion particles which are easily absorbed by plant roots. In addition, organic fertilizers contain complete nutrients, both macro nutrients and micro nutrients. These conditions are not possessed by artificial fertilizers. According to Eifediyi and Reminson (2010) organic fertilizers can maintain plants through a better recycling system of nutrients and improve the physical attributes of the soil. Increasing the weight of commercial crop ha ${ }^{-1}$ is also due to the increase in the diameter of the commercial $\mathrm{crop}^{-1}$, the fresh weight of the $\mathrm{ha}^{-1}$. This is evidenced by the positive correlation between the weight of commercial crop ha ${ }^{-1}$ and the weight of $\mathrm{crop} \mathrm{ha}^{-1}(\mathrm{r}=0.997 * *)$, the diameter of the commercial $\operatorname{crop}^{-1}(\mathrm{r}=0.976 * *)$ and the fresh weight of the ha ha ${ }^{-1}(\mathrm{r}=0.808 * *)$. Judging from the dosage of organic fertilizer treatment it turned out to have a significant effect on the yield of cabbage plants. Zulkifli and Herman (2012) stated that organic fertilizers contain nitrogen (N), phosphorus $(\mathrm{P})$, and potassium $(\mathrm{K})$ nutrients which are low, but contain nutrients abundant micro and needed for plant growth. 


\section{CONCLUSIONS AND SUGGESTIONS}

\section{Conclusion}

Based on the results of the research and discussion above, it can be concluded that:

1. The interaction between the treatment of spacing and the use of doses of organic fertilizer has no significant effect on all observed parameters.

2. Treatment of spacing has a significant effect on diameter commercial $\mathrm{crop}^{-1}$, stover fresh weight ha ${ }^{-1}$, and has a very significant effect on the weight of crop ha ${ }^{-1}$, and commercial crop weight $\mathrm{ha}^{-1}$. The highest weight of commercial crop ha ${ }^{-1}$ was obtained at a plant spacing of $30 \times 50 \mathrm{~cm}\left(\mathrm{~J}_{3}\right)$ of $525.86 \mathrm{~kg}$, significantly increasing by $75.80 \%$ compared to a spacing of $30 \times 30 \mathrm{~cm}\left(\mathrm{~J}_{1}\right)$ which was $299.12 \mathrm{~kg}$.

3. The treatment of the dosage of organic fertilizer has a very significant effect on the weight of crop ha ${ }^{-1}$, the weight of commercial crop ha ${ }^{-1}$, the commercial diameter of crop $^{-1}$ but has no significant effect on the fresh weight of stover ha ${ }^{-1}$. The highest weight of commercial ha ${ }^{-1} \mathrm{krop}$ obtained at the dose of organic fertilizer $2 \mathrm{t} \mathrm{ha}^{-1}$ of $444.23 \mathrm{~kg}\left(\mathrm{P}_{2}\right)$ increased by $58.30 \%$ compared to the dose of $0 \mathrm{t} \mathrm{ha}^{-1}\left(\mathrm{P}_{0}\right)$ of $280.62 \mathrm{~kg}$.

\section{Suggestions}

Based on the above conclusions, the following can be suggested:

Cabbage planting in areas with environmental conditions is almost the same as the research site using $30 \mathrm{~cm}$ $\mathrm{x} 50 \mathrm{~cm}$ spacing and $2 \mathrm{tha}^{-1}$ organic fertilizer to increase cabbage yield.

\section{REFERENCES}

Bambang Lamusi., Fitria S. Bagu., Fitriah S. Jamin,2014. Response to Growth and Results of Cucumber (Cucumissativus L.)Plants by Giving Petroganic Fertilizers. Department of Agrotechnology, Faculty of Agriculture, Gorontalo State University

Erwin S., Ramli.,Adrianton, 2015. Effect of Various Planting Spaces on Growth and Production of Cabbage (Brassica Olereaceae L) On the Middle Plains of Bobo Village, Palolo Sub-District, Sigi District. Agrotekbis 3 (4): 491 - 497, August 2015. ISSN: 2338-3011

Gomez, K.A., Gomez, A.A,1995. Statistical Procedures for Agricultural Research. Jakarta: University of Indonesia (translation)

Gomies, L. H, Rehata. J, Nandissa, 2012. Effect of RII Liquid Organic Fertilizer on Growth and Production of Flower Cabbage Plants (Brassica aloracea var. Botrytis L.). Agrologia.Journal of Plant Cultivation.Volume 1 Number 2 October 2012 Page 14.

Karnata, N., Sukasana, W., Turaini Indra Winten. K, 2012. Increasing the Quantity and Quality of Shallot Bulbs by Treatment of Petroganic Fertilizers and Weight of Bulbs.Untab Scientific Magazine Vol.9 No.1

Lingga, P., Marsono, 2004. Directions for Using Fertilizers. Jakarta: Spreading Self-Help

Mulat, T.2003. Make and use vermicompost, quality organic fertilizer, Jakarta: Agromedika Library

Rukmana, H, 2005. Planting Cabbage. Yogyakarta: Kanisius

Purnama, R.H., SartonoJokoSantosa., Sri Hardiatmi, 2013. Effect of Compost Water Hyacinth Dose Fertilizer and Planting Distance on the Growth and Yield of Sawi (Brassica Juncea L.) Plant ".Agricultural Innovation Journal Vol. 12, No. October 2nd, 2013

Sunarjono, H. 2004. Planting 30 Types of Vegetables. PT Penebar Swadaya, Jakarta. 58 p

J. Suprapto,1992. Sampling Techniques for Survey and Experiments, Rinika Cipta.

Talkah, A , 2007. Study of the Use of Petroganic Organic Fertilizers with Different Doses on the Growth and Production of Melon Plants (Cucumismelo L.) Oriental Varieties Produced at Branches 4, 8, and 12. Journal of Agritek.Vol. 16 No.June 6, 2008 Page 1147 - 1148.

Wisardja, I PM, 2011.The Corn Response of Bisi-16 Super Hybrid Varieties at Various Population Densities Due to Petroganic Fertilizer in Irrigated Rice Fields. Journal of GanecSwara. Vol. 5 No. 2 Page 7476.

Zulkifli and Herman,2012.Response of Sweet Corn (Zea mays saccharataStut) Prepared Dosage and Type of Organic Fertilizer.Faculty of Agriculture UIR.Riau. 